\title{
Revistas Brasileiras de Radiologia. Novos Rumos
}

\author{
Edson Marchiori, Giovanni Guido Cerri, Jacob Szejnfeld
}

A busca constante pela excelência levou as diretorias do Colégio Brasileiro de Radiologia e da Sociedade Paulista de Radiologia, e os editores das revistas Radiologia Brasileira e Revista da Imagem, a tomar uma série de decisões, dando novos rumos e perspectivas para estas revistas. As metas principais foram torná-las mais úteis para a comunidade radiológica, e tentar a indexação de pelo menos uma delas em bancos internacionais.

Uma avaliação crítica do momento atual deixou claro que seria impossível a indexação das duas revistas em bancos internacionais de alto nível, como o Medline, banco de dados da National Library of Medicine do National Institute of Health, dos Estados Unidos. Esta indexação é de fundamental importância, porque dá aos nossos trabalhos e pesquisas muito mais visibilidade, uma vez que passam a ser lidos e conhecidos por toda a comunidade científica internacional.

Assim, a estratégia traçada foi definir perfis diferentes para as duas revistas. De comum acordo entre as editorias dos dois periódicos (que na verdade vão se tornar um corpo editorial único), já a partir do início de 2006 a Radiologia Brasileira passará a ter um cunho mais acadêmico, concentrando artigos originais, resultantes de pesquisas mais complexas, e terá uma versão em inglês, on-line, adaptando-se às regras internacionais, necessárias para a indexação no Medline. A Revista da Imagem passará a publicar prioritariamente artigos de revisão, relatos de casos, artigos práticos do tipo "como eu faço", ensaios pictóricos, ou outras sessões, conforme juízo dos editores. Será uma revista mais prática e ágil, menos presa a normas rígidas, o que certamente a tornará muito mais valorizada, útil e importante para a maioria dos radiologistas brasileiros. O critério para esta escolha foi o fato de a Radiologia Brasileira estar indexada no banco de dados SciElo, que é um passo inicial para a indexação no Medline.

Esperamos com isso valorizar as duas revistas, cada uma com um objetivo específico. Alguns trabalhos avaliados ou em fase de avaliação poderão ser remanejados de uma para a outra, seguindo estes critérios. Esperamos que os autores compreendam que, no momento, as duas têm circulação e importância semelhantes, e que este remanejamento não irá criar nenhum prejuízo. Ao contrário, devido ao acúmulo de material para ser publicado na Radiologia Brasileira, haverá redução na espera da publicação dos artigos, o que certamente é do interesse de todos.

Estas medidas, temos certeza, irão contribuir para o que todos nós queremos: o engrandecimento da Radiologia do Brasil. 